\title{
Pengaruh Pemberian Ekstrak Taoge (Vigna radiata L.) Pada Mencit Jantan (Mus musculus) Terhadap Jumlah Anak Yang Dilahirkan
}

\author{
Nunuk Hidayanti*, Riski Sulistiarini, Adam M. Ramadhan, Laode Rijai \\ Laboratorium Penelitian dan Pengembangan FARMAKA TROPIS \\ Fakultas Farmasi Universitas Mulawarman, Samarinda, Kalimantan Timur \\ *Email : nunuehidayanti@gmail.com
}

\begin{abstract}
ABSTRAK
Infertilitas merupakan salah satu masalah kesehatan reproduksi yang serius yang dihadapi oleh sebagian masyarakat. Taoge (Vigna radiata L.) diyakini masyarakat sebagai peningkat kesuburan alami. Taoge memiliki kandungan antioksidan yang cukup tinggi yaitu vitamin $\mathrm{E}$, vitamin $\mathrm{C}$, fenol, flavonoid, fitosterol dan beberapa mineral seperti selenium, mangan, tembaga, zink dan besi. Penelitian ini bertujuan untuk mengetahui pengaruh pemberian ekstrak taoge terhadap perubahan jumlah anak pada hewan uji mencit. Hewan uji dibagi menjadi 4 kelompok secara acak yaitu kontrol normal tanpa pemberian ekstrak taoge, kelompok uji 1,2 dan 3 diberi ekstrak taoge dengan konsentrasi $12,5 \% ; 25 \%$ dan $50 \%$. Pengujian ini menggunakan metode breeding sistem poligami dengan cara mengawinkan mencit jantan dan betina (1:2) hingga diperoleh anak mencit selanjutnya dihitung jumlah anak dan ditimbang bobot lahir anak mencit secara keseluruhan dan dianalisis secara deskriptif. Pemberian ekstrak taoge memberikan pengaruh terhadap perubahan jumlah anak pada hewan coba mencit jika dibandingkan dengan kontrol normal. Konsentrasi terbaik ekstrak taoge dalam meningkatkan jumlah anak kelahiran dan bobot lahir adalah konsentrasi $25 \%$.
\end{abstract}

Kata kunci: Taoge (Vigna radiata L.), jumlah anak, mencit

\begin{abstract}
Infertility is one of reproduction health problem that have been faced by some society. Bean sprout (Vigna radiata $L$.) is believed by the public as a natural fertility enhancers. Bean sprout contains high antioxidants are vitamin $E$, vitamin $C$, phenols, flavonoids, phytosterols and some mineral such as selenium, mangan, copper, zinc and iron. This research has purpose to figuring the effects of giving bean sprout juices to the child amount changes of experiment mice. This experiment consist of 4 group randomly which are normal control breeding without bean sprouts juice treatment, experiment's group 1,2 and 3 have given bean sprouts juice with 12,5\%; $25 \%$ and $50 \%$ concentration. This experiment was using breeding method polygamy system by male mice mated with female mice (1:2) to obtain mice. Next step was to calculate the amount of mice and weighed the birth weight mice
\end{abstract}


and analyzed descriptively. Feeding mice with bean sprout juice gives more effect to the change of mice birth amount if we compare with normal control breeding. The effective concentration of bean sprout juice for the change of mice birth amount was $25 \%$ concentration.

Keyword: Bean sprout (Vigna radiata L.), child amount, mice

\section{PENDAHULUAN}

Infertilitas adalah suatu keadaan dimana tidak memiliki anak setelah 1 tahun menjalani aktifitas seksual secara regular tanpa menggunakan teknik kontrasepsi apapun (Putri, 2016). Sekitar $10 \%$ dari pasangan suami-istri mengalami infertilitas. Faktor penyebab infertilitas dapat berasal dari suami,istri atau keduanya. Faktor penyebab yang berasal dari suami sebesar 33,3 \% sedangkan hasil penelitian WHO sebesar $40 \%$ (Khaidir, 2006). Infertilitas pada pria mencapai angka 48,4\% dari kasus infertilitas di Indonesia (Syauqi, 2015).

Di Indonesia, terdapat beberapa tanaman dan sayuran yang diyakini oleh masyarakat sebagai peningkat kesuburan alami. Salah satu sayuran yang telah digunakan oleh masyarakat untuk meningkatkan kesuburan pria adalah kecambah kacang hijau (taoge). Masyarakat mengkonsumsi kecambah kacang hijau ini dalam bentuk sayuran (mentah/dimasak) atau dibuat dalam bentuk jus.

Taoge kacang hijau dikenal masyarakat sebagai tanaman peningkat kesuburan pria. Dharanindya (2015) menyatakan bahwa taoge memiliki kandungan antioksidan yang cukup tinggi diantaranya vitamin E ( $\alpha$ tokoferol), vitamin $\mathrm{C}$, fenol, flavonoid, fitosterol dan beberapa mineral (selenium, mangan, tembaga, zinc dan besi). Menurut penelitian Basir (2013) pemberian nutrisi kecambah kacang hijau (Vigna radiata) pada Mus musculus meningkatkan kepadatan spermatozoa sebesar 11,05 juta/cc sperma (kontrol) dan 11,78 juta/cc sperma (perlakuan). Selain itu, menurut penelitian Diartha (2016) pemberian ekstrak taoge berpengaruh positif dalam meningkatkan motilitas spermatozoa serta meningkatkan jumlah spermatozoa pada mencit jantan.

Oleh karena itu penelitian ini dilakukan untuk mengetahui pengaruh pemberian ekstrak taoge (Vigna radiata L.) terhadap perubahan jumlah anak yang 
dilahirkan pada hewan coba mencit (Mus musculus) dengan menghitung jumlah anak dan bobot lahir secara kumulatif menggunakan timbangan analitik.

\section{METODE PENELITIAN}

\section{Bahan}

Bahan yang digunakan dalam penelitian ini adalah aquadest, pakan standar, taoge kacang hijau.

\section{Peralatan}

Peralatan yang digunakan dalam penelitian ini yaitu blender, cawan porselen, corong kaca, gelas kimia $50 \mathrm{~mL}$, kaca arloji, labu ukur $100 \mathrm{~mL}$, timbangan analitik, sendok tanduk, spoid oral $1 \mathrm{~mL}$ dan sonde mencit.

\section{PROSEDUR PENELITIAN}

\section{Penyiapan Sampel}

Sampel yang digunakan adalah taoge kacang hijau yang masih segar. Taoge kacang hijau dipisahkan dari bagian yang tidak diinginkan hingga diperoleh taoge kacang hijau segar yang kemudian akan dibuat menjadi pakan jus taoge.

\section{Pembuatan Pakan Jus Taoge}

Taoge kacang hijau segar yang telah diperoleh ditimbang sebanyak 100 gram dan kemudian dilakukan proses pembuatan pakan jus taoge. Pakan jus taoge dibuat dalam 3 stok seri konsentrasi yaitu $12,5 \% ; 25 \%$ dan $50 \%$. Untuk membuat konsentrasi 12,5\%, sebanyak 12,5 g taoge kacang hijau segar ditambah aquades hingga $100 \mathrm{~mL}$ dan diblender. Pakan jus taoge kacang hijau konsentrasi $25 \%$ dan $50 \%$ dibuat dengan cara yang sama dengan stok pakan jus taoge konsentrasi 12,5 $\%$.

\section{Pengujian Breeding}

Pengujian dilakukan dengan memberikan jus taoge sesuai dengan konsentrasi masing-masing kelompok untuk 3 kelompok pengujian dan tanpa pemberian jus taoge untuk kelompok kontrol normal selama 14 hari. Penelitian ini menggunakan 12 ekor mencit jantan dewasa dan 24 mencit betina dewasa. Hewan uji mencit terlebih dahulu diaklimatisasi selama satu minggu. 7 hari pertama mencit jantan dioralkan jus taoge dan ditempatkan dalam kandang terpisah dengan mencit 
betina. Kemudian 7 hari berikutnya, mencit jantan dikumpulkan dengan mencit betina dalam satu kandang dengan perbandingan mencit jantan dan betina 1:2 (sistem poligami). Mencit betina yang terlihat hamil dipisahkan dari kandang perkawinan dan dipelihara dalam kandang sendiri hingga proses kelahiran anak mencit. Dilakukan pengumpulan data berupa jumlah anak kelahiran per induk dan bobot lahir kumulatif pada masing-masing kelompok perlakuan.

\section{HASIL DAN PEMBAHASAN}

Pengujian dilakukan untuk mengetahui pengaruh penggunaan pakan jus taoge terhadap jumlah anak dan bobot lahir kumulatif pada hewan coba mencit. Jumlah anak dan bobot lahir kumulatif yang diperoleh pada konsentrasi jus taoge 12,5\%; $25 \%$ dan $50 \%$ akan dibandingkan dengan kelompok kontrol normal tanpa pemberian pakan jus taoge. Parameter pakan jus taoge dalam mempengaruhi jumlah anak dan bobot lahir kumulatif hewan uji mencit pada penelitian ini adalah apabila jumlah anak hewan uji dan bobot lahir kumulatif hewan uji pada perlakuan pakan jus taoge kacang hijau lebih tinggi dibandingkan dengan kelompok kontrol normal tanpa pemberian pakan jus taoge. Jumlah anak dan bobot lahir kumulatif diperoleh setelah masing-masing induk betina beranak. Jumlah anak diperoleh dengan cara menghitung jumlah anak yang lahir dari masing-masing induk mencit betina pada hari-1 kelahiran. Bobot lahir kumulatif anak per kelahiran diperoleh dengan cara menimbang semua anak yang lahir dari satu induk betina. Rata-rata jumlah anak yang dilahirkan masing-masing kelompok perlakuan dapat dilihat pada Tabel 1.

\section{Tabel 1. Rata-rata Jumlah Anak Yang Dilahirkan}

\begin{tabular}{lc}
\hline \multicolumn{1}{c}{ Kelompok } & $\begin{array}{c}\text { Rata-rata } \pm \\
\text { SD (ekor) }\end{array}$ \\
\hline Kontrol normal & $3,8 \pm 3,20$ \\
Konsentrasi $12,5 \%$ & $6,6 \pm 3,78$ \\
Konsentrasi $25 \%$ & $8,2 \pm 1,92$ \\
Konsentrasi $50 \%$ & $5,6 \pm 4,50$ \\
\hline \multicolumn{1}{c}{$\mathrm{n}$} & 5 \\
\hline
\end{tabular}

Berdasarkan pada Tabel 1, diperoleh hasil bahwa pemberian pakan jus taoge pada konsentrasi $12,5 \%$, 25\% dan 50\% memiliki rata-rata jumlah kelahiran pada 
hewan coba masing-masing adalah 6,6; 8,2 dan 5,6 ekor. Sedangkan rata-rata jumlah kelahiran pada hewan coba yang tanpa pemberian pakan jus taoge sebesar 3,8 ekor. Secara deskriptif dapat dilihat bahwa konsentrasi pemberian $25 \%$ memiliki rata-rata jumlah kelahiran yang paling besar dibandingkan dengan kelompok perlakuan lainnya. Hal ini menandakan bahwa pemberian pakan jus taoge pada mencit berpengaruh terhadap jumlah kelahiran anak mencit.

Diartha (2016) menyatakan bahwa pemberian ekstrak taoge berpengaruh positif dalam meningkatkan motilitas spermatozoa serta meningkatkan jumlah spermatozoa pada mencit jantan. Peningkatan sperma oleh pemberian taoge akan berpengaruh pula terhadap peningkatan jumlah anak per kelahiran oleh hewan uji mencit. Dharanindya (2015) menyatakan bahwa taoge memiliki kandungan antioksidan yang cukup tinggi diantaranya vitamin $\mathrm{E}$, vitamin $\mathrm{C}$, fenol, flavonoid, fitosterol dan beberapa mineral. Berdasarkan penelitian yang dilakukan oleh Momeni (2009) bahwa pemberian vitamin E konsentrasi $100 \mathrm{mg} / \mathrm{kg} / \mathrm{hari}$ memberikan efek pada peningkatan berat testis, jumlah sperma, motilitas sperma, produksi estrogen,meningkatkan kelangsungan hidup dan perkembangan sperma tikus yang dipapar timbal. Vitamin E merupakan antioksidan yang dapat melindungi spermatozoa dari berbagai kerusakan akibat serangan radikal bebas, sehingga dengan adanya vitamin $\mathrm{E}$ di dalam taoge maka spermatozoa yang dihasilkan jumlahnya akan semakin banyak karena ada kemungkinan vitamin $\mathrm{E}$ tersebut yang akan melindungi spermatozoa dari berbagai kerusakan.

Rata-rata bobot lahir kumulatif pada masing-masing kelompok perlakuan dapat dilihat pada Tabel 2.

Tabel 2. Rata-rata Bobot Lahir Kumulatif

\begin{tabular}{ll}
\hline \multicolumn{1}{c}{ Kelompok } & Rata-rata \pm SD $($ gram) \\
\hline Kontrol normal & $4,48 \pm 3,28$ \\
Konsentrasi $12,5 \%$ & $9,78 \pm 4,24$ \\
Konsentrasi $25 \%$ & $12,02 \pm 2,98$ \\
Konsentrasi $50 \%$ & $8,2 \pm 7,65$ \\
\hline \multicolumn{1}{c}{$\mathrm{n}$} & \multicolumn{1}{c}{5} \\
\hline
\end{tabular}


Berdasarkan data pada Tabel 2, diperoleh hasil bahwa pemberian jus taoge pada konsentrasi $12,5 \%$; $25 \%$ dan $50 \%$ memiliki rata-rata bobot kelahiran kumulatif pada hewan coba masing-masing adalah 9,78; 12,02 dan 8,2 gram. Sedangkan jumlah kelahiran pada hewan coba tanpa pemberian pakan jus taoge sebesar 4,48. Sama halnya pada data jumlah kelahiran, secara deskriptif dapat dilihat bahwa konsentrasi pemberian 25\% memiliki rata-rata bobot kelahiran yang paling besar dibandingkan dengan kelompok pemberian lainnya. Rata-rata bobot lahir kumulatif hewan uji masing-masing perlakuan berbanding lurus dengan jumlah anak per kelahiran hewan uji mencit.

\section{KESIMPULAN}

Pemberian pakan jus taoge memberikan pengaruh terhadap jumlah anak yang dilahirkan pada hewan coba mencit. Rata-rata jumlah anak yang dilahirkan pada pemberian pakan jus taoge konsentrasi 12,5\%, $25 \%$ dan $50 \%$ adalah 6,6; 8,2 dan 5,6. Sedangkan rata-rata jumlah anak yang dilahirkan untuk kelompok kontrol normal tanpa pemberian pakan jus taoge sebesar 3,8. konsentrasi terbaik pakan jus taoge yang dapat memberikan pengaruh terhadap jumlah anak yang dilahirkan hewan coba mencit adalah konsentrasi $25 \%$.

\section{SARAN}

Sebaiknya perlu dilakukan pengujian lebih lanjut secara mikroskopik untuk melihat dan menghitung jumlah spermatozoa secara jelas, serta perlu diteliti kandungan senyawa dalam taoge yang dapat berpengaruh terhadap parameter reproduksi.

\section{DAFTAR PUSTAKA}

Basir, Anastasia A., Hassan, Munif S., Buranda, Theophillus dan Ferial, Eddyman W. 2013. Pengaruh Pemberian Nutrisi Phaseolus radiates L. terhadap Tingkat Kepadatan Spermatozoa Mus musculus L. Jurnal Ilmiah Biologi. 1. (1).

Dharanindya, Galuh Ica Manohara., Normasari, Rena., dan Febianti, Zahrah. 2015. Pengaruh Pemberian Ekstrak Taoge Kacang Hijau (Vigna radiate L.) 
terhadap Ketebalan Tunika Intima-Media Aorta Abdominalis pada Tikus Wistar Jantan yang Diberi Stres Fisik. e-Jurnal Pustaka Kesehatan. 3. (3).

Diartha, I Wayan Wena., Sudatri, Ni Wayan dan Setyawati, Iriani. 2016. Pengaruh Pemberian Ekstrak Taoge Ditambah Madu terhadap Kualitas Spermatozoa Mencit Jantan. Jurnal Simbiosis. IV. (1).

Khaidir, Masrizal. 2006. Penilaian Tingkat Fertilitas dan Penatalaksanaannya pada Pria. Jurnal Kesehatan Masyarakat. 1. (1).

Momeni, Hamid, R., Mehranjan, Malek, S., Abnosi, Mh., Mahmoodi \& Monireh. 2009. Effects of Vitamin E on Sperm Parameters and Reproductive Hormones in Developing Rats Treated With Para-Nonylphenol. Iranian Journal of Reproductive Medicine 7 (3).

Putri, Indrani Nur Winarno dan Saftarina, Fitria. 2016. Pengaruh Sindrom Polikistik Ovarium terhadap Peningkatan actor Risiko Infertilitas. Jurnal Majority. 5. (2).

Syauqi, Ahmad. 2015. Ekspresi Enzim Metabolisme Vitamin D pada Sistem Reproduksi Pria. Jurnal JMJ. 3. (1). 